\title{
Mary Wollstonecraft e Nísia Floresta: diálogos feministas
}

\author{
Raquel Martins Borges Carvalho Araújo ${ }^{1}$
}

\begin{abstract}
RESUMO: Em 1832, Nísia Floresta Brasileira Augusta publicou a "tradução livre" do livro A vindication of the rights of woman de Mary Wollstonecraft. Este trabalho consiste na análise das obras A vindication of the rights of woman de Mary Wollstonecarft e Direito das mulheres e injustiça dos homens de Nísia Floresta. Será abordada a questão da "antropofagia literária" realizada por Nísia Floresta e a polêmica em torno do diálogo ou a apropriação entre as duas obras.

ABSTRAC: In 1832, Nísia Floresta Brasileira Augusta published the "free translation" of the book A vindication of the rights of woman by Mary Wollstonecraft. This paper consist on the analysis of the books A vindication of the rights of woman by Mary Wollstonecraf and Direito das mulheres e injustiça dos homens by Nísia Floresta. We are going to examine literary anthropophagy done by Nísia Floresta and the polemic issue about dialog or appropriation between the books.
\end{abstract}

PALAVRAS-CHAVE: Mary Wollstonecraft, Nísia Floresta, tradução cultural. KEYWORDS: Mary Wollstonecraft, Nísia Floresta, cultural translation.

\section{$\underline{\text { I Introdução }}$}

Este trabalho objetiva fazer uma analise comparativa das obras Vindication of rights of woman (publicada em 1791) da escritora feminista inglesa Mary Wollstonecraft (1759-1797) e de Direito das mulheres e injustiça dos homens (publicada em 1832) de Nísia Floresta Brasileira Augusta, pseudônimo de Dionísia Gonçalves Pinto (1810-1885) ${ }^{2}$.

O trabalho da Dra. Constância Lima Duarte colaborou de forma decisiva para a produção deste artigo. Esta grande pesquisadora dedicou-se por mais de vinte anos ao resgate da obra de Nísia Floresta que, apesar de atualmente ser considerada a primeira feminista do Brasil, sua "vida e obra mantiveram-se praticamente desconhecidas durante muitos anos", segundo a pesquisadora Rachel Soihet (2005, p.193) da Universidade Federal Fluminense. Durante anos, Duarte visitou várias cidades brasileiras e do exterior recolhendo importantes escritos da autora. Seu trabalho meticuloso resultou na divulgação de várias obras de Nísia Floresta que há muito tempo o público deixou de ter conhecimento, além da produção de uma rica obra biográfica

\footnotetext{
${ }^{1}$ Licenciada em Letras Inglês pela Universidade de Brasília. Trabalho de Iniciação Científica, orientado pela professora Dra. Cristina Stevens.

${ }_{2}^{2}$ A obra Wollstonecraft, no decorrer deste trabalho, será referida como Vindication apenas.
} 
sobre a autora. Os artigos acadêmicos em que Constância dialoga com os textos de Nísia Floresta foram de grande valia para a melhor compreensão das obras.

A biografia de Mary Wollstonecraft redigida pela pesquisadora e integrante da Royal Society of Literature, Lyndall Gordon, foi igualmente imprescindível para realização desta pesquisa, visto que viabilizou a compreensão do universo de Wollstonecarft por meio de meticulosos relatos de sua vida pessoal e por disponibilizar uma vasta quantidade de correspondências ao longo da obra.

Conforme destaca o historiador Gilberto Freire em seu livro, Sobrados $e$ Mucambos (2002, p. 141), Nísia Floresta surgiu como "exceção escandalosa (...) no meio de homens a dominarem sozinhos todas as atividades extradomésticas, as próprias baronesas e viscondessas mal sabendo escrever, as senhoras mais finas soletrando apenas livros devotos e novelas (...)". Em um período em que mulher apenas existia no âmbito doméstico, Nísia Floresta recusou-se a ser subserviente à autoridade patriarcal. Além de dirigir um colégio, publicou vários livros e textos na jovem imprensa nacional. Essa figura de causar "pasmo", como aponta Gilberto Freire; recebeu em troca o manto negro do esquecimento além da difamação pessoal, conforme destaca Duarte (2005, p. 15). Duarte (2003) explica que Nísia pagou um alto preço por estar tão à frente de seu tempo, visto que não teve o seu talento reconhecido, o que explica o fato de o seu nome não constar nem na historiografia literária brasileira tradicional, e nem sequer integrar os grandes nomes na história das mulheres ou da educação feminina até a segunda metade do século XX.

Em 1832, Nísia Floresta Brasileira Augusta publicou a "tradução livre" do livro Vindication de Mary Wollstonecraft. A obra, escrita quando autora tinha apenas 22 anos que lhe conferiu a atribuição de percussora do feminismo não somente no Brasil como também na América Latina. Para entender as diferenças e semelhanças que circundam as duas obras destas autoras, faz-se necessário a melhor compreensão dos fatores históricos que envolveram a produção de cada um dos textos. Outro aspecto relevante, que será estudado no presente trabalho, reporta-se a "antropofagia literária" realizada por Nísia Floresta e a polêmica questão envolvendo o diálogo ou a apropriação entre Direito das mulheres e injustiça dos homens e Vindication.

$\underline{\text { II Contexto histórico da obra de Mary Wollstonecarft }}$ 
Mary Wollstonecarft nasceu em Londres em 1759 durante a vigência do Ato de Harwicke (1753) que dava ao marido amplos poderes sobre a esposa, sendo essa desprovida de direitos patrimoniais, direitos sobre os filhos e até mesmo do direito à proteção a integridade física dentro de sua própria casa. A vida doméstica de Mary Wollstonecraft é marcada pela presença "despótica" e "cruel" do seu pai e pela figura "submissiva" da mãe, conforme destaca Godwin (1798). O senhor Wollstonecraft dispensava à sua esposa o mesmo tratamento fornecido aos cachorros, sujeitando-a as suas inconstantes variações de humor (Gordon, 2005, p. 11). A respeito da violência doméstica sofrida pelas mulheres, a pesquisadora francesa de história das mulheres e gênero Michelle Perrot (2007, p. 77) destaca que "a quantidade de mulheres que apanhavam dos maridos era imensa. Bater na mulher e nos filhos era considerado um meio normal, para o chefe de família ser o senhor de sua casa - desde que fizesse com moderação". Frequentemente, Mary Wollstonecraft se interpunha entre o pai e a mãe, a fim de evitar as agressões, conforme afirma Godwin (1798).

Os estudos iniciais de Mary Wollstonecraft foram realizados por conta própria, pois, naquela época, as mulheres eram educadas exclusivamente para desempenhar o papel de esposa e mãe. Argumentos como os de Rousseau, que ilustraremos a seguir, eram largamente difundidos na sociedade: "uma vez que se demonstrou que o homem e a mulher não são e nem devem ser constituídos da mesma maneira, nem quanto ao caráter, nem quanto ao temperamento, segue-se que não devem ter a mesma educação" (ROUSSEAU, 2004, p.524). Perrot salienta que o saber era contrário à feminilidade por ser um atributo sagrado e privilégio dos homens, representantes exclusivos de Deus na terra. A objeção à instrução feminina era tão forte que em 1801, após a morte de Wollstonecraft (1797), ainda encontramos um projeto de lei contendo a proibição de se ensinar às mulheres a ler. No texto de autoria do Sylvain Maréchal (1750-1803), filósofo, poeta e teórico político francês, constam artigos repletos de objeções: "Quer a razão que as mulheres não metam jamais o nariz num livro, jamais a mão numa pena", "Que escândalo e discórdia num lar quando a mulher sabe tanto quanto o marido" (Marechal, 1801 apud Perrot, 2007, p.93).

Diante do contexto extremamente adverso à educação feminina, devem-se evidenciar algumas influências que foram expressivas na vida intelectual e política de Wollstonecraft. O ministro Richard Price da Capela Unitariana de Newington Green foi quem a introduziu no círculo de intelectuais composto por Joseph Priestley, Thomas 
Paine, William Wordsworth, Samuel Taylor Coleridge, William Blake, e William Godwin, conforme aponta Luis Worth Jones. Seu editor, Joseph Johnson, também foi um importante apoio em sua vida intelectual; Mary Wollstonecraft tinha-o referência paterna.

Wollstonecraft viveu na França durante o período revolucionário e participou ativamente dos debates entre os intelectuais da época. Ela acreditava que a verdadeira civilidade, só poderia existir entre iguais (Gordon, 2005, p. 145). Lutou ao lado de mulheres e homens, a fim de que os ideais de liberdade, igualdade e fraternidade alcançassem também o sexo feminino.

Marquês de Condorcet no documento "On Giving Women the Right of Citizenship" (1790) questiona o fato de se invocar o direito a cidadania para 300 ou 400 homens que, devido a um absurdo preconceito, foram privados dos direitos políticos, mas se esquecem de 12 milhões de mulheres. Em 1791, a percussora do feminismo francês, Olympe de Gouges, a partir da Declaração dos direitos dos homens (1789) divulga um novo texto propondo a concessão às mulheres de amplos direitos a cidadania. No preâmbulo da Declaração dos direitos das mulheres, Gouge frisa que "a ignorância, o esquecimento e o desinteresse dos direitos da mulher são as únicas causas das calamidades públicas e da corrupção dos governos; estas decidiram expor em uma declaração solene os direitos naturais, inalienáveis e sagrados da mulher."

Deve-se frisar que o universo de Wollstonecraft era profundamente marcado pela contradição entre as idéias liberais nos círculos intelectuais do século XVIII e a tentativa de manutenção do aprisionamento das mulheres no âmbito privado, conforme sobreleva Perrot (1997). Sobre essa incoerência, Perrot (1997, p. 93) ressalta que, apesar da Revolução Francesa ter tentado "subverter a fronteira entre o homem público e privado, construir um homem novo, remodelar o cotidiano através de uma nova organização do espaço, do tempo e da memória, (...) esse projeto grandioso fracassou diante da resistência das pessoas". Em relação à delimitação dos espaços de atuação de cada sexo, Hunt (1997, p. 51) explica que "os próprios revolucionários sentiram a necessidade de marcar um limite intransponível, de mostrar claramente que as mulheres estavam no lado privado e os homens no lado público". Todavia, quando um processo revolucionário se inicia, é impossível mantê-lo restrito a um determinado aspecto da sociedade. O tremor de uma revolução abala a sociedade como um todo e o impacto acaba gerando fissuras em todos os seus níveis. As contradições, por anos abafadas, 
ressurgem fortes; afinal, como falar de liberdade, igualdade e fraternidade se não é relegada a condição de cidadão à metade dos seres humanos?

$\underline{\text { III Contexto histórico da obra de Nísia Floresta Brasileira Augusta }}$

A escritora Dionísia Gonçalves Pinto ${ }^{3}$ nasceu no dia 12 de outubro de 1810 em Papari, Rio Grande do Norte. Filha de Dionísio Gonçalves Pinto Lisboa, advogado português, e Antônia Clara Ferreira. Casou-se aos treze anos, mas, no mesmo ano, separou-se e voltou a residir com os pais. Em 1828, passa a morar com o seu companheiro Manuel Augusto de Faria, acadêmico de Direito. Dessa união, nascemlhes dois filhos: Lívia Augusta Faria da Rocha, que posteriormente se tornaria sua tradutora, e Augusto Américo de Faria Rocha.

Antes de examinar os questionamentos das duas autoras sobre a opressão feminina, é importante compreender o tamanho do abismo que separa o contexto das duas obras. Enquanto Wollstonecraft clama pelo direito à educação as mulheres, o Brasil contava com uma estrutura educacional totalmente incipiente. O historiador Luis Carlos Villalta (2001, p. 357) afirma que em “1818 quando as reformas já estavam sedimentadas, apenas $2,5 \%$ da população masculina livre, em idade escolar, era atingida pelas aulas régias em São Paulo". Esse dado possibilita-nos compreender que o empenho somente pela educação feminina não era o bastante, visto que o sistema educacional como um todo era precário e não atingia a maior parcela da população.

Nísia Floresta nasceu em uma época em que a ignorância do povo brasileiro era convenientemente administrada pela metrópole por meio do ensino " bem dosado" da catequese, pois não há melhor ciência do que a da salvação, conforme afirma o padre Antônio Viera. O historiador Boris Fausto (2002, p. 60) destaca quão relevante foi o papel da igreja neste período: "como tinha em suas mãos a educação das pessoas, o controle da alma na vida diária, era um instrumento muito eficaz para veicular a idéia geral de obediência e, em especial, a de obediência ao poder do Estado”.

Não bastava o clamor pelo acesso à educação restrita aos homens, pois, em nosso contexto, nem sequer existia um sistema educacional consolidado como o da Europa. Nísia Floresta "pesa" a utilidade da mulher na sociedade brasileira e destaca as virtudes tão importantes à sociedade, que são comumente desvalorizadas pelos homens. A adaptação feita por Nísia Floresta à realidade local brasileira depara-se justamente

\footnotetext{
${ }^{3}$ Informações biográficas retiradas do livro: DUARTE, Constância Lima. Nísia Floresta: a primeira feminista do Brasil. Santa Catarina: Editora Mulheres, 2005.
} 
com nossas peculiaridades culturais, já que nosso ponto de partida situava-se em uma coordenada completamente distinta da européia. Era preciso "pesar" e medir utilizando os nossos próprios parâmetros. A esse respeito, Duarte faz a seguinte colocação:

Como pleitear uma instrução mais consciente se mesmo a alfabetização mais superficial esbarrava em toda sorte de preconceitos? E, mais ainda, como pleitear emancipação política se as mulheres ainda precisavam ser consideradas seres pensantes? Esta pode ser uma das razões que explica o fato de Nísia Floresta haver optado por fazer uma adaptação em lugar simplesmente de uma tradução. (DUARTE, 2003, p. 3)

A autonomia da mulher brasileira era ainda bem mais restrita do que a Européia. Mary Del Priore tece algumas observações que tornam mais nítidos a situação injusta que preponderava em nossa pátria:

No máximo, as mulheres se expunham na varanda dos sobrados, penteando os longos cabelos ou catando piolho, uma das outras, e esperando a hora de rezar as ave-marias. Chamadas de senhoras ou donas, tinham como única aspiração o casamento. Casamento com parente, com amigos da família, enfim, com gente igual. Os maridos podiam ser velhos feios e doentes. Ficar solteira, ou "no caritó", como se dizia, era castigo. (PRIORE, 2008, p. 15)

Contudo, no século XIX, conforme observa Priore (2006, p. 236) ocorre um afrouxamento gradativo desse controle. Ainda assim, Gilberto Freire, Sobrados e Mucambos (2002, p. 140), ressalta que mulheres como Nísia Floresta foram "excomungadas da ortodoxia patriarcal". Freire (2002, p. 143) destaca que mesmo na metade do século XIX com a urbanização do sistema patriarcal ${ }^{4}$ as oportunidades de intervenção femininas continuaram a ser insignificantes. Elas ainda eram "reduzidas a formas graciosas e quase inócuas".

"Nunca numa sociedade aparentemente européia, os homens foram tão sós no seu esforço, como os nossos no tempo do Império; nem tão unilaterais em sua obra política, literária, científica. Unilaterais pela falta, não tanto de inspiração da mulher - que está houve, e das mais intensas, sobre os poetas e os romancistas do Império - mas do que se poderia chamar de simpatia criadora." (FREIRE, 2002, p. 144)

A ausência de uma figura feminina que estivesse em pé de igualdade com o seu marido a ponto de compreendê-lo e ajudá-lo em seus problemas marcou profundamente este período, o que acabou por favorecer o aparecimento do "narcisismo ou o monossexualismo sob formas intelectuais", conforme destaca Freire (2002, p. 144). Em 1872, o médico, Correia de Azevedo responsabilizou a "mãe indolente, inculta", ao lado da "ama escrava" e "da mucama imoral" pelo fato do menino brasileiro perder-se tão cedo (FREIRE, 2002, p. 144). Pode-se observar que o patriarcalismo reinante criou o

\footnotetext{
${ }^{4}$ Gilberto Freire utiliza esse termo para se referir as modificações sofridas no sistema patriarcal no período do segundo reinado com o primeiro surto industrial e com a urbanização crescente.
} 
modelo de figura feminina "franzina", "pálida", "virgem" e "graciosa" que, com o casamento, tornava-se a mulher "gorda", "caseira", "procriadora". Percebe-se nestes atributos uma forte relação de oposição com a figura viril, forte e ativa masculina. Gilberto Freire (2002, p. 146) afirma que as mulheres "morriam velhas aos vinte e cinco anos, no oitavo ou nono parto, sem outra intimidade com o marido que a da cama patriarcal”.

Em antagonismo latente com a realidade local, Nísia Floresta, conforme aponta Duarte (2008, p. 143), provoca surpresa e grande admiração em " todos que se detiveram sobre sua figura (...) surpresa por haver existido naquele tempo uma mulher tão consciente da sua capacidade e de seus direitos, num contraste (...) com a grande maioria das suas contemporâneas".

IV Análise comparativa das duas obras

A obra, Direito das mulheres e injustiça dos homens, de Nísia Floresta não corresponde a uma tradução, em seu sentido original, e muito menos a um plágio do livro de Wollstonedraft. Cada autora possui seu estilo e direciona o texto a um público específico, o europeu e o brasileiro, respectivamente. Os livros partem de reflexões oriundas de contextos históricos bem distintos, mas possuem em comum a posição crítica e questionadora sobre a condição de opressão da mulher na sociedade. Desse modo, os traços distintivos que serão aqui apontados são características que particularizam ainda mais cada uma dessas obras. São elementos que saltam ao olhar, quando nos deparamos com as duas obras.

Constância Lima Duarte (2001, p. 155) no artigo intitulado, Nísia Floresta e Mary Wollstonecraft: diálogo ou apropriação?, descarta qualquer hipótese de plágio entre as duas obras, visto que é notória a intencionalidade da autora brasileira de adaptar o texto inglês à realidade de seu país, buscando conscientizar as mulheres brasileiras sobre os seus direitos. Essa temática é recorrente nas obras de Nísia Floresta. Desse modo, não se trata, portanto, de um texto isolado, como pode ser observado pela sua própria biografia. Nísia Floresta foi uma mulher totalmente a frente de seu tempo e sempre analisou de forma crítica os fatores por trás da opressão feminina em seu país e a condição de vida da mulher em outros lugares que teve oportunidade de conhecer. No livro, Cintilações de uma alma brasileira (publicado em 1859), por exemplo, Nísia Floresta avalia o comportamento da mulher francesa e a recrimina por mandar seus filhos recém-nascidos para a aldeia, a fim de que venham ser criados pelas camponesas. 
Estas crianças longe das mães e em condições péssimas de higiene, escassa alimentação e cuidados, dificilmente passavam da primeira infância.

Os textos da autora inglesa e da autora brasileira se aproximam pela forte denúncia à opressão feminina e pela defesa ao acesso a uma educação de qualidade a todas as mulheres. Contudo, os contextos históricos bastante distintos somados ao público que cada uma das obras foi destinada marca de forma expressiva as diferenças entre os dois livros que serão pormenorizadamente analisadas no decorrer deste trabalho.

O livro, Vindication, é composto por 13 capítulos que tratam basicamente da condição da mulher na sociedade sobre várias perspectivas diferentes. Podemos destacar alguns temas comumente abordados: educação feminina, relação familiar, moral, costumes e crenças da época em relação à mulher, dentre outros. Sobre o processo de construção da obra, Janaina Gomes Fontes (2008, p. 71) em sua dissertação de mestrado afirma:

Em Vindication, manifesto escrito com ardor em apenas seis semanas, Wollstonecraft expressa com impetuosidade suas visões sobre a real e crua situação das mulheres na época, quando a esperança de mudança radical se espalha pela Europa com os desdobramentos da Revolução Francesa.

O livro de Nísia Floresta, Direito das mulheres e injustiça dos homens, é composto por seis capítulos e foi escrito quatro décadas depois da obra de Wollstonecraft, com base na edição francesa. Na capa, consta que o livro se trata de uma tradução livre da obra de Wollstonecraft. Duarte (2003, p.2) afirma que o texto concernente à realidade de vida da mulher européia funcionou como elemento motivador para que a escritora promovesse uma "acomodação das mesmas idéias ao cenário nacional”. Nísia Floresta não realiza uma tradução, mas sim escreve outro texto sobre os direitos das mulheres, inspirada pelo trabalho de Wollstonecraft, consoante Duarte (1997, p. 2) A antropofagia literária ${ }^{5}$ promovida por Nísia Floresta, conforme Duarte (2003, p. 2) , não é uma opção, mas sim uma "fatalidade histórica". Sobre esse texto percussor do feminismo brasileiro, Duarte (1997, p. 3) ressalta:

Vejo-o como uma resposta brasileira ao texto inglês; a nossa autora se colocando em pé de igualdade com a Wollstonecraft e até com o pensamento europeu, e cumprindo o importante papel de elo entre as idéias européias e a realidade nacional.

\footnotetext{
5 A antropofagia literária consiste na apropriação do texto Europeu não para produzir uma replica, mas para metamorfoseá-lo com elementos da cultura local.
} 
A obra é dividida em três momentos distintos, conforme destaca Duarte (2005, p. 35), "inicia-se como se fosse uma ficção; transmuda-se em autêntica crônica com anotações sobre o comportamento humano; e termina emitindo reflexões de cunho filosófico com nítido propósito didático".

Mary Wollstonecraft dedica seu livro a Charles Maurice de Talleyrand-Périgord, bispo de Autun, embaixador e primeiro ministro Francês. Ao perceber a força do movimento revolucionário, Talleyrand-Périgord uniu-se a ele e, como membro do comitê constitucional, participou da elaboração da Declaração dos direitos dos homens (1789). Este documento privava a mulher do direito a cidadania, sendo, em (1791) proposto por Olympe de Gouge a partir deste documento a Declaração dos direitos das mulheres. $\mathrm{O}$ bispo de Autun também foi o autor do documento Rapport sur linstruction publique (1791) criticado duramente por Wollstonecraft.

Após provocar o bispo com a dedicatória, a autora realiza quase que um debate com ele, refutando sua proposta, justificando a própria posição e sugerindo, no penúltimo capítulo do Rights of woman..., um audacioso plano de educação nacional, em muito diferente do seu. (DUARTE, 2008, p. 147)

Mary Wollstonecraft afirma que as mulheres são, desde novas, preparadas para a escravidão do casamento. A força física do homem, ao longo do tempo, serviu como fator legitimador para a superioridade masculina, todavia, Wollstonecraft ressalta que tanto o homem como a mulher são criaturas racionais e devem ter suas virtudes aperfeiçoadas por meio da educação.

Nísia Floresta (1989, p 21) dedica o seu livro às brasileiras e aos jovens acadêmicos. As mulheres são aconselhadas a continuarem a buscar o conhecimento e a prática da virtude, afim de que os homens reconheçam que "o Céu nos há destinado para merecer na Sociedade uma mais alta consideração". Já a mocidade acadêmica é alvo das esperanças de mudança; Nísia Floresta espera que "algum dia nas horas vagas de vossos altos ministérios, lançareis vistas de justiça sobre nosso sexo em geral" (1989, p. 22)

Enquanto Mary Wollstonecraft clama por uma NOVA CONSTITUIÇÃO ${ }^{6}$ que desse a mulher direitos civis iguais aos fornecidos aos homens e, concomitantemente, o acesso a uma educação igualitária, Nísia Floresta, cautelosamente, fala à suas patrícias e pede que a nova geração de intelectuais de seu país encontre um tempo para examinar sua causa. Duarte (2003, p. 3) destaca que "o bom senso estaria, portanto, na percepção

\footnotetext{
${ }^{6}$ As palavras escritas com letras maiúsculas seguem a forma como Wollstonecraft escreveu em seu texto.
} 
da distância que existia entre a situação cultural da Europa e do Brasil (...) e na consciência da defasagem cultural, social, política e econômica, existente entre centro e periferia".

Wollstonecraft pede JUSTIÇA, ao fim da sua dedicatória, para metade da raça humana que, apesar de todo processo revolucionário vivido na França, ainda continuava sem dignidade e direito a cidadania. Já Nísia Floresta (1989, p. 22) convida os acadêmicos a examinar a sua causa. Ainda que esse essa apreciação não resulte em uma "metamorfose na ordem presente das coisas", poderá conceder "uma melhor sorte" às mulheres.

Nísia Floresta adere à doutrina iluminista amplamente divulgada em Pernambuco no seu tempo; ela busca fundamentar as relações de moral, verdade e virtude conforme os estóicos. Para isso, utiliza como "balança" o utilitarismo (DUARTE, 2003). A autora apresenta sua causa ao leitor e o convida a realizar um exame judicioso das idéias que os homens concebem do sexo feminino, pesando sempre a medida da utilidade de cada um dos lados nos argumentos utilizados.

\begin{abstract}
Em uma palavra, se os homens fossem Filósofos (tomando a palavra em seu rigor) descobririam facilmente que a Natureza constituiu uma perfeita igualdade entre os dois sexos. Mas como há poucos que sejam capazes de um pensar tão abstrato, nenhum direito tem mais que nós de serem Juízes nessa matéria, e por conseqüência precisamos recorrer a um Juiz menos parcial, incapaz de deixar-se prevenir por alguma das partes e, por conseguinte, irrecusável. (FLORESTA, 1989, p. 30)
\end{abstract}

Nísia Floresta inverte a relação de superioridade masculina para inferioridade. "De seres considerados socialmente inferiores, as mulheres seriam, na verdade, superiores aos homens em qualquer dos aspectos que se considerasse. E mais, afirma reiteradas vezes: os homens insistem no domínio da força física e as mantém na mais completa ignorância, justamente por saberem que elas lhes são superiores". Duarte ${ }^{7}$ (1989, p. 117) elucida claramente o raciocínio de Nísia neste parágrafo:

Extrapolando o raciocínio de Mary Wollstonecraft, Nísia Floresta tenta inverter a relação: de mulheres inferiores socialmente, ela acredita e quer provar a superioridade feminina frente aos homens. Superioridade essa, diga-se de passagem, que o 'sexo invejoso e pouco generoso' oculta, para melhor dominar através da fora física e do despreparo intelectual feminino.

Mary Wollstonecraft, todavia, não defende essa tese, pois afirma que não deseja que as mulheres tenham poder sobre os homens, mas sim sobre si mesmas. Durante sua

\footnotetext{
${ }^{7}$ DUARTE, Constancia lima. posfácio. In: AUGUSTA, Nísia Floresta Brasileira. Direitos das mulheres e injustiça dos homens. 4 ed. São Paulo: Cortez, 1989.
} 
obra, Wollstonecraft empenha-se mais conscientizar o leitor da importância de se oferecer educação de igual qualidade para os homens e as mulheres.

Constância Lima Duarte (1989) aponta alguns elementos importantes no posfácio da última edição do livro de Nísia Floresta. Entre eles, pode-se destacar o jogo de oposição entre mulher e homem armado por Nísia Floresta a começar no título da obra que deixa claro a relação de oposição existente entre os direitos das mulheres versus injustiça dos homens. A forma como a autora habilmente utiliza-se de recursos retóricos para transformar desvantagens em vantagens. $\mathrm{O}$ movimento pendular entre a ironia com que a autora se refere aos homens e a ternura em relação às mulheres. Uma outra diferença entre os textos são as marcas intertextuais. Mary Wollstonecraft elege Rousseau, Milton, Shakespeare, John Gregory, David Hume, Anna Laetitia Barbauld, Adam Smith, Bíblia, entre outros textos para tecer um diálogo ao longo de sua obra. Já Nísia Floresta opta por Descartes, Platão, Aristóteles, Alexander Pope, Marco Pórcio , Galeno, entre outros. Wollstonecraft elegerá. Primordialmente, Rousseau enquanto Floresta escolhe Catão, "filósofo bem divulgado no Brasil via cultura portuguesa" (DUARTE, 1989, p. 121). As diferentes escolhas podem ser atribuídas à popularidade dos autores selecionados no país de origem de cada uma das autoras. Era necessário que os leitores tivessem conhecimento das obras mencionadas para que entendessem a estrutura argumentativa construída ao longo da obra.

A doutrina utilitarista é a base estrutural da argumentação de Nísia Floresta, mas não de Mary Wollstonecraft. Segundo Abbagnano (2000, p. 987), “o utilitarismo é uma corrente do pensamento ético, político e econômico inglês dos séculos XVIII e XIX". A palavra foi empregada de forma ocasional pela primeira vez por Jeremy Bentham em 1781. O utilitarismo foi uma tentativa de transformar a ética em "ciência positiva da conduta humana". A fórmula que sintetiza melhor essa corrente do pensamento filosófico foi dita por Cesare Beccaria (1764 apud 2000, p. 987) "a maior felicidade possível, compartilhada pelo maior número possível de pessoas".

A doutrina utilitarista foi o instrumento de medida utilizado por Nísia Floresta, para determinar o valor do homem e da mulher dentro da sociedade. É possível observar claramente sua utilização no trecho subseqüente:

Todos concordam em respeitar as pessoas à proporção de sua utilidade; eis pois a medida de seu merecimento. Ora, sendo esta regra aplicável a todas as circunstâncias da vida, por que não devem ter as mulheres, mais que todos, direito à estima pública, contribuindo mais, sem comparação, a seu bem-estar? (DUARTE, 1989, p. 37) 
No decorrer da obra, a autora brasileira pesará habilmente em sua balança utilitarista o papel de ambos os sexos na sociedade. Ela enfatiza que todos os feitos heróicos e grandiosos dos príncipes e ministros cuja "ambição é o único móvel" e a segurança promovida pelos juízes e magistrados não são nada perto da contribuição feminina que os nutri, educa e estima na primeira infância. Nísia Floresta questiona se qualquer um deles poderia "passar sem amas na sua infância?" (1989, p. 37)

Logo no início de Vindication, Mary Wollstonecarft ressalta que enquanto Rousseau aplica-se em provar que tudo era bom originalmente, tecendo uma crítica à teoria do bom selvagem e a uma multidão de autores crê que agora tudo é justo. Ela se propõe a provar que somente no futuro essa justiça existirá. Neste capítulo inicial, ela introduzirá a situação de preconceito, atacando suas bases religiosas e filosóficas. Já Nísia Floresta discorre sobre a crença segundo a qual as mulheres foram criadas para o uso do homem e propõe provar ser verdadeiro justamente o inverso. A capacidade de criar e nutrir os filhos tão desprezada pela sociedade tornaria a mulher merecedora do primeiro lugar na sociedade, pois todos os homens foram na infância dependente de sua ama, segundo Floresta. No final deste capítulo, Nísia Floresta propõe examinar as razões que sustentam a argumentação de que as mulheres não são capazes de manter-se a luz da razão para que o leitor possa decidir sobre a veracidade dessa opinião com conhecimento de causa.

Wollstonecarft critica o estado de infância, eterna obediência e passividade que foi relegada às mulheres. O escritor inglês John Milton é questionado por sua descrição da figura feminina como um ser doce e cegamente obediente, privado de alma. A figura tirânica do homem sobre suas irmãs, filhas e esposas é duramente recriminada pela autora que enxerga a educação como única forma de livrá-las desse estado de escravidão.

Eu permitirei que a força corporal dê aparentemente ao homem a superioridade natural sobre a mulher, e essa é a única base sólida que a superioridade do sexo pode ser construída. Entretanto, eu insisto, que não somente na virtude, mas também no conhecimento ambos os sexos sejam o mesmo em natureza, se não em grau, e que a mulher considerada não só moral, mas também considerada criatura racional, e devem se empenhar em adquirir virtudes humanas (excelências) da mesma maneira que os homens ao invés de serem educadas como um tipo ornamental de meio ser, uma das selvagens quimeras de Rousseau. (WOLLSTONECRAFT, 1996, p. 38)

Logo a diante, Wollstonecarft (1996, p. 44) evidencia que é tempo de uma revolução na conduta feminina, tempo de restaurar a dignidade perdida e fazer delas, 
como parte da espécie humana, trabalhadoras, mudando elas mesmas para melhorar o mundo. A autora destaca que seu sexo encontra-se escravizado e totalmente educado para uma vida de dependência.

Nísia Floresta desenvolve as seguintes questões: se as mulheres são inferiores aos homens, quanto ao entendimento; se elas são próprias a preencher os cargos públicos, se são capazes de ensinar as ciências, se são próprias para os empregos. Nísia Floresta destaca que as mulheres são capazes de exercer qualquer cargo com a mesma responsabilidade dos homens, contudo, são privadas por não terem "ciência".

Um dos pontos de grande contraste entre as duas obras refere-se à educação moral da mulher. Nísia Floresta reforça o "ideal feminino", baseado em uma visão completamente idealizada de esposa, mãe e filha, segundo Duarte (2008). Duarte também ressalta que tanto Nísia Floresta como outras escritoras da época lutaram contra a figura da mulher mundana e voltada aos prazeres da carne. O trecho subseqüente ilustra o posicionamento da autora: "Mas é a abnegação de vós mesma em prol de sua felicidade e glória, aquilo de que vós deveis procurar dar prova: é, sobretudo, a grande obra do porvir que deveis ter em vista, sacrificando a vosso próprio bem e todos vossos passatempos" (Floresta, 1997a, p. 143 apud Duarte, 2008, p. 260). Nísia Floresta defendia a educação feminina, mas essa era voltada para os deveres morais. A autora não questionou pontos como o direito a cidadania plena por parte das mulheres. Todavia, Mary Wollstonecarft destaca esses aspectos em seu manifesto. Deve-se considerar como um dos fatores determinantes o momento de profundos questionamentos políticos vivido pela autora inglesa durante o período da Revolução Francesa, visto que Wollstonecarft residiu na França durante aquele período e participou ativamente dos encontros da elite intelectual.

As reivindicações dos direitos da mulher, tal como é formulada por Mary Wollstonecarft, provém de uma consciência aguda das transformações necessárias não apenas nas instituições que regem as sociedades (ponto essencial e indispensável), mas também na consciência dos indivíduos, na nova atitude que eles deverão adotar frente a si mesmos e frente aos outros, como indivíduos e como grupos sociais. (PENIGAULTDUHER, 1984, p. 433 apud DUARTE, 2008, p. 158,)

No período em que Nísia Floresta publicou Direito das mulheres e injustiça dos homens, na Europa, se discutia a maior participação da população nas decisões políticas, o déficit orçamentário do governo, a ordem social vigente e as tensões ocasionadas com o advento da revolução industrial, o Brasil ainda amargava sua dependência política em relação a Portugal. A atividade industrial era controlada pela metrópole e poucos eram 
letrados, neste contexto, falar de uma mudança na consciência dos indivíduos em uma nação que nem liberta era, seria muita precipitação. Constância Lima Duarte (1989) afirma que "os ideais de liberdade a empurraram, mas ela estava à mercê de forças antagônicas, é preciso sempre lembrar, e o conservadorismo a puxa para trás. Nísia, realmente, é em todos os sentidos, fruto do seu tempo".

Wollstonecraft (1996) ressalta que a mulher não deve ser considerada um ser de natureza exclusivamente moral, mas também criaturas racionais que não foram criadas para satisfazer o apetite masculino ou para servi-lhes de serva. A autora inglesa critica os direitos "divinos" dos maridos sobre suas esposas e o estado deplorável em que se encontram as mulheres, pois a verdade lhes é ocultada, vivem em um condição de ignorância tendo constantemente seus pensamentos direcionados pelos homens. Wollstonecarft chama a atenção para a necessidade de separação dos princípios morais imutáveis e os hábitos locais, promovendo, assim, uma revolução nos hábitos de vida das mulheres. Durante seu manifesto, é também comum encontrar críticas a educação coqueteira, voltada unicamente a desenvolver habilidades relacionadas ao jogo de sedução.

\section{Conclusão}

Apesar de os textos estarem centrados na mesma motivação: fazer uma reflexão crítica acerca do papel da mulher na sociedade, cada um deles percorre um caminho diferente, marcado por um momento histórico específico de cada país. Duarte (2008, p. 148) destaca que "se bem diferente era o nosso momento e ainda mais elementares nossas necessidades".

Mary Wollstonecraft defendia que a emancipação da mulher viria por meio do acesso a uma educação de qualidade, enquanto, para Nísia, a educação funcionaria como um meio de aperfeiçoar as virtudes da alma feminina, "quanto nossos defeitos são insuperáveis e se nos negam os meios para nos corrigir" (FLORESTA, 1989, p. 93). Nísia Floresta (1989, p. 90) frisa que "a falta do saber e da educação, que arrasta as mulheres às ações que os homens reprovam, as priva das virtudes que poderiam sustentá-las contra os maus tratamentos que imprudentemente lhes fazem sofrer”.

Mary Wollstonecraft reforça que a educação trará um vínculo de companheirismo entre o homem e a mulher, pois estes estarão em pé de igualdade perante a sociedade e aptos a desempenhar seu papel como cidadãos. A base sólida amizade e o companheirismo entre o casal, segundo a escritora, são imprescindíveis 
para se garantir uma boa educação às crianças. Wollstonecraft defende que somente o conhecimento trará a possibilidade de desenvolvimento das virtudes na alma feminina. Ela ressalta que as diferenças entre os gêneros que os homens tanto insistem são arbitrárias e justifica que um relacionamento conjugal sólido não pode subsistir entre pessoas que, praticamente, não partilham de nada em comum.

Podemos destacar que ambas enxergam a educação como um meio de capacitar a mulher para o exercício mais consciente da maternidade, mas Wollstonecraft vai mais adiante nas suas considerações e na sua proposta emancipatória para as mulheres. Nísia Floresta (1997, p. 133 apud DUARTE 2008, p. 261) acreditava ser "a melhor virtude que condiz convosco; a abnegação". Duarte (2008) afirma que, ao enfatizar "a educação moral", Nísia Floresta tocou "nas mesmas teclas de outros pensadores, em tudo contrários a uma ampla emancipação da mulher". A educação serviria como um instrumento para conscientizar a mulher de seus deveres na sociedade, ou seja, aceitar o seu melhor destino que, segundo Duarte (2008, p 261) seria viver sua feminilidade.

Mary Wollstonecarft salientou a importância de uma revolução que mexesse profundamente nas estruturas sociais, pois não haverá igualdade enquanto a metade da população, isto é, as mulheres, permanecerem a margem dos direitos e garantias constitucionais. Nísia Floresta, todavia, deu os primeiros passos para a desconstrução de os preconceitos que envolviam o seu sexo. Pode-se considerar que as duas obras foram extremamente significativas para a história do feminismo, visto que tiveram como um de seus grandes méritos: questionar o papel que era imposto à mulher em sua sociedade.

\section{Bibliografia}

ABBAGNANO, Nícola. Dicionário de filosofia. 4. ed. São Paulo: Martins Fontes, 2000.

AUGUSTA, Nísia Floresta Brasileira. Direitos das mulheres e injustiça dos homens. 4 ed. São Paulo: Cortez, 1989.

CONDORCET, Marquise. On Giving Women the Right of Citizenship. 1790. Disponível em: <http://www.pinn.net/ sunshine/book-sum/condorcet4.html>. Acesso em: 17 ago. 2009.

DE GOUGES, Olympe. Declaration of the Rights of Woman. 1791. Disponível em: <http://www.library.csi.cuny.edu/dept/americanstudies/lavender/decwom2.html>. Acesso em: 17 ago. 2009.

DUARTE, Constância Lima. Feminismo e literatura: discurso e história. In Revista Estudos Avançados da USP. São Paulo, USP, v. 17, n. 49, set. /dez. 2003. p. 151-172 DUARTE, Constância Lima. Nísia Floresta: a primeira feminista do Brasil. Santa Catarina: Editora Mulheres, 2005. 
DUARTE, Constância Lima. Nísia Floresta e Mary Wollstonecraft: diálogo ou apropriação? In: O Eixo e a Roda. Revista de Literatura Brasileira da Faculdade de Letras da UFMG. Belo Horizonte, vol. 7, 2001.

DUARTE, Constância Lima. Nísia Floresta Brasileira Augusta: Pioneira do

Feminismo Brasileiro - Séc. XIX. Mulheres e literatura. ano 1. vol. 1. 1997.

Disponível em: <http://www.litcult.net/revistamulheres_vol1.php?id=7>. Acesso: 30 dez. 2008.

DUARTE. Constância Lima. Nísia Floresta: vida e obra. Natal: EDUFRN, 2008.

FAUSTO, Boris. História do Brasil. 11. ed. São Paulo: EDUSP, 2002

FONTES, Janaina Gomes. A voz materna: Mary Wollstonecraft e Michèle Roberts.

2008. 140 p. Dissertação (mestrado) - Universidade de Brasília, Departamento de Teoria Literária e Literaturas, 2008.

FREYRE, Gilberto. Sobrados e mucambos: introdução a história da sociedade patriarcal no Brasil - 2. 13. ed. Rio de Janeiro: Record, 2002.

GAUTHEROT, Gustave. Charles-Maurice de Talleyrand-Périgord. The Catholic Encyclopedia. Vol. 14. New York: Robert Appleton Company, 1912. Disponível em: <http://www.newadvent.org/cathen/14434b.htm>. Acesso em: 19 ago. 2009.

GODWIN, William. Memoirs of Mary Wollstonecarft. (1978) Disponível em: <http://dwardmac.pitzer.edu/Anarchist_archives/godwin/memoirs/toc.html>. Acesso em: 4 jan. 2009.

GORDON, Lyndall. Vindication - A life of Mary Wollstonecraft. New York, NY: Happer Perennial, 2005.

JONES, Worth Louis. Mary Wollstonecraft. Disponível em:

<http://www25.uua.org/uuhs/duub/articles/marywollstonecraft.html >. Acesso em: 8 fev. 2009.

PERROT, Michelle. Minha história das mulheres. São Paulo: Contexto, 2007.

PERROT, Michelle. A família triunfante. In: PERROT, Michelle. Historia da vida privada: Da revolucao francesa a primeira guerra. Sao Paulo: Companhia das Letras, 1997.

PRIORE, Mary del. Condessa de Barral - A paixão do imperador. São Paulo: Objetiva, 2008.

PRIORE, Mary del. História do amor no Brasil. 2. ed. São Paulo: Contexto, 2006.

Rectifying An Old Mistake. New york Times. 13/05/1987. Disponível em:

<http://www.nytimes.com/1987/05/13/us/rectifying-an-old-

mistake.html?pagewanted=print $>$.Acesso em : 06 dez. 2008

SOIHET, Rachel. Nísia Floresta e mulheres de letras no Rio Grande do Norte: pioneiras na luta pela cidadania. Revista Estudos Feministas [online]. 2005, vol.13, n.1 [cited 2009-08-18], pp. 193-195 . Disponível em:

<http://www.scielo.br/scielo.php?script=sci_arttext\&pid=S0104-

026X2005000100016\&lng=en\&nrm=iso>. ISSN 0104-026X. doi: 10.1590/S0104-

026X2005000100016>. Acesso em: 17 ago. 2009.

VILLALTA,Luiz Carlos. O que se fala e o que se lê: língua, instrução e leitura. In: História da vida privada no Brasil: cotidiano e vida privada na América portuguesa. São Paulo: Companhia das Letras, 1999. v.1. p. 332-385.

WOLLSTONECRAFT, Mary.(1971). A vindication of the rights of woman. 2 ed. New York: Dover Thrift, 1996. 